NBER WORKING PAPER SERIES

\title{
HOUSING FINANCE IN THE UNITED STATES
}

IN THE YEAR 2001

\author{
Patric H. Hendershott \\ Kevin E. Villani \\ Working Paper No. $\underline{739}$
}

\section{NATIONAI BUREAU OF ECONOMIC RESEARCH \\ 1050 Massachusetts Avenue \\ Cambridge MA 02138}

August 1981

\begin{abstract}
Presented at "North American Housing Markets Into the 21st Century" Symposium, University of British Columbia, Vancouver, B.C., Canada, July 22-24, 1981. The study was supported by the Center for Real Estate Education and Res earch, The Ohio State University, from funds supplied by the Ohio Real Estate Education and Research Fund. The research reported here is part of the NBER's research program in Financial Markets and Monetary Economics and project in Capital Formation. Any opinions expressed are those of the authors and not those of the National Bureau of Economic Research.
\end{abstract}


Housing Finance in the United States in the Year 2001

\section{ABSTRACT}

This paper proceeds as follows. We first identify the essential services provided by a financial system and then derive the characteristics of the system that would exist in a technologically advanced society unfettered by nonneutral taxes and regulations. Next we consider how taxes and regulations have shaped the existing American financial structure. Finally, we posit likely tax and regulatory changes and conjecture as to how technological innovation will further interact with these changes to alter the American financial system. Our basic contentions are that the tax and regulatory influences are eroding and that the system will eventually move toward the unfettered financial system described in the first section.

Patric H. Hendershott

Krannert Graduate School of Management Purdue University West Lafayette, IN 47906 (317) 494-4421

Kevin E. Villani Department of Housing and Urban Development Office of Economic Analysis 4517 th Street, S.W. Washington, D.C. 20410 (202) 755-5980 


\section{Table of Contents}

$\underline{\text { Page }}$

I. The Essential Elements of Finance $\ldots \ldots \ldots \ldots \ldots \ldots \ldots \ldots \ldots, 2$

A. Essential Financial Services $\ldots \ldots \ldots \ldots \ldots \ldots \ldots \ldots \ldots \ldots \ldots \ldots$

B. Characteristics of an Unfettered Financial System ....... 5

II. The Current Housing Finance System $\ldots \ldots \ldots \ldots \ldots \ldots \ldots \ldots$, .

A. Tax Preferences and Regulations $\ldots \ldots \ldots \ldots \ldots \ldots \ldots \ldots, 10$

B. Debt Instruments and Returns $\ldots \ldots \ldots \ldots \ldots \ldots \ldots \ldots \ldots \ldots \ldots \ldots \ldots \ldots \ldots \ldots$

C. Underwriting, Brokerage and Exchange ................ 14

III. Evolution of the Housing Finance Structure $\ldots \ldots \ldots \ldots \ldots \ldots \ldots$

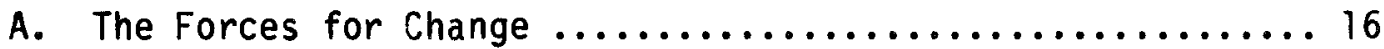

B. The Ultimate Financial Structure $\ldots \ldots \ldots \ldots \ldots \ldots \ldots . \ldots 19$

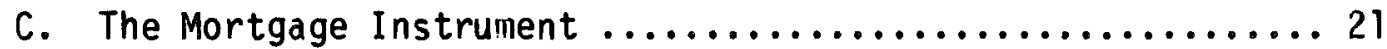

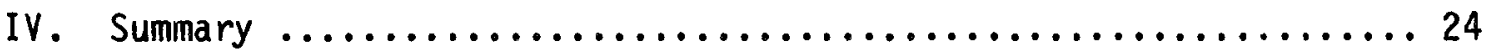

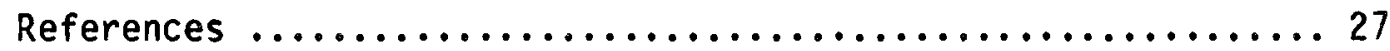



As the title suggests, this paper is an exercise in futureology. Such exercises are not uncommon. What distinguishes this attempt from the usual is the time frame; we view the system at the beginning of the next century rather than over the coming decade. This makes our task less difficult in one sense and more difficult in another: less difficult because the memory of 20 year forecasts is vague; more difficult because one needs to go beyond simple extrapolations of ongoing trends and to identify the underlying forces of change.

Had the time frame been shorter, e.g., a decade, a more traditional approach would suffice. This could entail:

1. a determination of "housing needs" through the next decade, based on extrapolations of household formation and demographic trends,

2. a calculation of the demand for "housing credit" these needs generate,

3. an estimate of the supply of housing credit from "traditional" sources, and

4. an assessment of the secondary market and federal policy response to the projected "gap" between the demand for and supply of housing credit.

This sort of analysis, al though somewhat useful for short time periods, is not very enlightening of the more distant future. The financial system is currently undergoing revolutionary changes. Lines of demarcation between banks, thrifts, other financial intermediaries, and industry are rapidiy eroding. Existing firms are expanding beyond traditional functions, and new firms are performing nontraditional functions as innovation renders 
regulatory boundaries obsolete. New financial institutions and instruments are developing in response to fundamental economic, regulatory and institutional forces. Identification of these forces and of the logical end to which they will lead is necessary to understand both current developments and the likely evolution of the housing finance system into the 21 st Century.

This paper proceeds as follows. First, we identify the essential services provided by a financial system and then derive the characteristics of the system that would exist in a technologically advanced society unfettered by nonneutral taxes and regulations. Next we consider how taxes and regulations have shaped the existing American financial structure. Finally, we posit likely tax and regulatory changes and conjecture as to how technological innovation will further interact with these changes to alter the American financial system. Our basic contentions are that the tax and regulatory influences are eroding and that the system will eventually move toward the unfettered financial system described in the first section.

\section{The Essential Elements of Finance}

The first step in understanding the financial structure and in distinguisining between regulatory and economic induced innovation is to identify those elements of finance that are essential to household portfolio optimization. 1 From this, the characteristics of a minimal financial sector (utilizing current technology) follow in a straight-forward manner.

$1 /$ See Silber (1975) for an enlightening discussion of financial systems and innovations. 
A. Essential Financial Services

We identify four essential financial services that would be provided in some form in any well-developed financial system: 1) a medium of exchange, 2) security underwriting, 3) security brokerage and 4) denomination intermediation. Each of these is discussed briefly in the remainder of this section.

1. Medium of Exchange. The first and most important financial service is the provision of a "nedium of exchange." Brunner and Meltzer (1971) have shown that the costs of exchanging goods in an uncertain world can be reduced if one good serves as a nedium of exchange. This medium, generally labeled money, must exhibit two characteristics. First, it should be generally acceptable. To accomplish this, it must convey information regarding its ability to be converted to real goods. Second, it should be "portable." The more portable it is, the greater are the efficiency gains it generates. As will be discussed later, technology is the limiting factor in conveying information and transporting money.

2. Security Underwriting. The second most important financial service is the provision of a financial claim that allows the transfer of income from surplus to deficit units [see Gurley and Shaw (1956)]. This transfer reallocates real resources from less useful or less productive activities to more productive activities. The key characteristic of this transfer is the information embodied in the financial claim regarding the probability the deficit unit will repay the surplus unit. The primary function of security underwriting is to identify the parameters affecting expost nominal returns and to provide information to surplus units to allow them to form reasonabie 
subjective probability distributions regarding the fiture value of these parameters and thus the probability that the terms of the contract will be met. Because a given value of a parameter may increase the expost nominal return on some instruments and decrease the return on others, diversification reduces the variability of portfolio returns.

3. Security Brokerage. The need for brokerage stems from the desire by households either to reallocate their portfolios or to change their net worth. The reallocation-induced denand for brokerage services arises primarily from differing expectations of future outcomes affecting portfolio returns. Secondarily, households reducing net worth (deficit units) need a mechanism to transfer assets to housenolds increasing net worth fsurplus units). Again, the essential characteristic of brokerage is the transfer of information between surplus and deficit households to facilitate the exchange.

4. Denomination Intennediation. Deficit units issue financial instruments that presumably reflect their needs and available collateral. There are two fundamental characteristics of these instruments. These are those parameters that affect expost nominal and real returns. A major benefit of finance is its contribution to superior allocation of risk bearing in the economy [Arrow (1964)]; this derives from the ability of economic units to diversify risks associated with multiple securities. The optimal portfolio for a household may include the obligations of many issuers, but in smaller amounts than are efficient for the issuer to supply. The major role of financial intermediaries is to provide these smaller denominations. 
Denomination intermediation also allows diversification of inflation risk through maturity intermediation. In a tax-neutral world, the real value of capital should be unaffected by inflation, anticipated or unanticipated. Thus, to the extent that financial contracts finance real assets, inflation does not affect real wealth. Human capital may be considered a real asset, but households cannot issue equity shares. Insofar as households issue debt contracts, which provide a claim on future nominal income, to increase current consumption above current income, the real value of those contracts will fall in response to an increase in inflation. To the extent that the inflation is unanticipated - not built into the contract interest rate - the real wealth of deficit units increases at the expense of surplus units. Theoretically, individual households can hedge their debt portfolios against uncertain inflation rates by either selling financial assets short or writing options contracts. But as long as some households issue claiins on future nominal income, unanticipated inflation will have distributional consequences.

In summary, there are few essential financial services. Deficit units would issue instruments reflecting the collateral -- either the market value of the asset or, in the case of unsecured debt, the income stream the unit produces. Some form of banks would be created to provide a medium of exchange, and some form of underwriters would develop to convey appropriate information regarding the return parameters of the instruments. Brokers would arise to facilitate the transfer of assets, and denomination intermediaries would be created to facilitate diversification of nominal and real risk.

\section{B. Characteristics of an Unfettered Financial System}

Before returning to the existing financial structure, it may be useful to speculate on the characteristics of a financial structure utilizing 
existing technology but unfettered by taxes, regulation or fixed institutional capital (hereafter institutional memory). In a subsequent section, we will contrast this system with the existing structure and identify the consequences of taxes, regulations and institutional menory.

Consider a simple world in which the private capital stock consists of residential and industrial capital. Producers of housing services and other goods and services would issue both ownership shares in individual units (or collections of units) of capital and debt instruments collateralized by individual units or collections of these units. We denote the demand for shares of the jth unit of capital by

$$
\hat{C}_{j}=f\left(P_{j}, d_{j}, \pi_{j}\right) \text {, }
$$

where $P_{j}$, the anticipated productivity of the $j$ th unit lor collection of units) of capital, $d_{j}$, the anticipated depreciation rate, and $\pi j$, the anticipated rate of price increase, are subjective probability distributions. We note that productivity is defined as the rents accruing to capital.

An interesting question is, are there any reasons why households would want to corner the ilarket on an individual housing unit? That is, would full homeownership exist in a well-developed financial system without tax preferences? Households desire managenent control to allow them to make all decisions regarding the use of this capital, just as some shareholders of industrial capital desire to maintain a majority interest, but, given the current management prerogatives of shareholders, this explains a 51 percent ownership share, not a 100 percent share. In fact, homeownership is most prevalent in very primative societies without financial systems. Rental markets exist in 
more developed societies and require a more developed financial system to sell equity shares. Expost returns on equity shares in different houses will vary for the same reason as they do on equity shares in different industrial plants and companies. That is, the actual returns will depend on the expost value of the parameters. Portfolio optimization implies diversification among shares in residental as well as industrial capital. What does all this imply for security supplies? Thus far, our analysis suggests the existence of supplies of equity shares financing residential and industrial capital and of debt collateralized by residential and industrial capital. Intermediaries will offer these four instruments in smaller denominations. Whether or not these are a sufficient number of instrunents for all households to optimize their portfolios, i.e., to reduce the benefits from further diversification to zero, depends on the characteristics of the debt instruments. This leads to a more fundamental question. That is, what information does the debt collateral convey?

Two of the three parameters in the demand functions for shares, $P_{j}$ and $d_{j}$, reflect the physical characteristics of the capital and are independent of the third parameter, inflation. This information is most fully utilized if:

1) the instruments offer a fixed real interest rate, and 2) the principal is repaid at the depreciation rate. The difference between debt and equity is that the risks embodied in $P_{j}$ and $d_{j}$ are borne mostly by the equity holders. A specific example may be useful here. Assume capital markets are efficient and there exists a security (governinent?) of maturity $k$ with a "certain" real rate of interest $r$. In risk neutral markets, the "most likely" or mean expected real return on a capital good with a life $k$ and no physical 
depreciation is also $r$. Suppose further that the capital good is one-half equity financed and one-half bond financed. The bondholders' expost yield is $r$ plus a small default premium $f$ so long as the equity share has positive value. The return on equity reflects the actual productivity and depreciation rates of this particular piece of capital and the extent of bond leveraging. In this case, if ex post earnings were twice those expected $(r)$, then the return to equity would be almost three times $(3 r-j)$ that expected.

The bond instrument described above contracts for the "most likely" real return on existing capital plus $f$. How does this differ from a perfectly diversified equity portfolio? The expected real return on the latter would reflect the mean value of the subjective probability distributions of the parameters $P_{j}$ and $d_{j}, i . e$. , the variance of these parameters for a perfectly diversified equity portfolio is zero. But suppose that subjective probabilities turn out to be wrong "across the board," resulting in a lower (or higher) expost return on capital generally. This will be reflected in the return on the perfectly diversified equity portfolio but not the bond return (unless the return on capital were markedly lower). The same certain return could be achieved with a diversified equity portfolio and options contracts. 2 That is, debt instruments are not an essential instrument of finance! Thus the primary consequence of bonds is on the distributional impact of the actual real earnings generated by existing capital.

\footnotetext{
2/ For example, suppose the holder of a perfectly diversified equity portfolio is extremely averse to actual productivity of capital generally falling short of exante expected productivity. He can write a contract, the value of which depends on the difference between actual and expected productivity. If $\mathrm{fe}$ is the expected forward price and $\mathrm{f}^{\mathrm{a}}$ the actual forward price, the difference will reflect the difference between expected and actual productivity. The options contract would simply give the writer the ability to "put" the equity shares into the portfolio of the holder of the option at fe.
} 
We have thus far ignored instruments to finance consumption in excess of income. These "unsecured" instruments are collateralized by the productivity or earnings potential of human capital. Conceptually, at least, there would exist equity and debt instruments with characteristics sinilar to those financing nonhuman capital.

If all households shared the saine expectations and were risk-neutral, then no other nonmoney financial instruments would exist. 3 If expectations regarding inflation differed, then some households would write options to other households reflecting these differences, and an options market could develop.

\section{The Current Housing Finance System}

Our previous discussion implied that $1 /$ residential capital would be financed with equity shares and mortgage debt, 2) mortgage underwriters would originate real-denominated housing finance instruments, and 3)

financial institutions would develop as pooling arrangements to facilitate diversification by lowering minimum denominations. The existing housing finance system differs in important respects froin this hypothetical model. Equity shares in residential capital are scarce; mortgage instruments pay nominal returns; and "housing finance" intermediaries have undiversified portfolios. In this section we attenpt to explain the roles that taxes, regulation, and institutional memory have played in the formation of the current system.

3/

It takes time to produce capital, and the production period is uncertain. Consequently, optional delivery markets would develop for real and financial instruments. 
A. Tax Preferences and Regulations

The most important consequences of current tax law stem from the failure to tax imputed rent on owner-occupied housing and the preferential treatiment of capital gains for homeowners. This explains why almost two-thirds of all households own their own hones and the ownership rate is higher for higher-income households. ${ }^{4}$ This, in turn, gives rise to mortgage instruments collateralized by individual housing units and to many households having real housing assets far in excess of their net worth. As a consequence, the total stock of financial debt is dramatically increased, and most household balance sheets are extremely undiversified and leveraged. Because of the latter, the return to household net wort'n varies far more than proportionately with the returns on individual houses for these homeowners.

The ultimate constraint on arbitrage between owner-occupied housing and financial markets is the diminishing marginal utility of housing services. In equilibrium, wealthier households (and those lower income households for whom hoineownership does not pay) ultimately finance the owner-occupied housing of middle-income households. There is a general loss to society in that benefits of diversification are foregone. In addition, the portfolios of wealtinier households will be tilted toward nore debt and less equity. There are thus distributional consequences to other than the "most likely" outcones of $P_{j}, d_{j}$ and, particularly, $\pi_{j}$.

$4 /$ See Hendershott and Shilling (1981) and Rosen and Rosen (1980) for analysis of the deterinination of tenure choice in the U.S. 
The second major tax policy affecting the housing financial system is the preferential tax treatinent of incone from mortgages held in thrift institution portfolios. Currently savings and loans are allowed to put up to 40 percent of their earnings into a "bad debt" reserve without paying federal tax on the income so long as at least 82 percent of their assets are invested in residential mortgages. 5 Virtually all institutions have been induced to meet this requirement. This, comined with regulatory prohibitions (or threats of the same) against variable-rate loans, has resulted in an industry with a substantially undiversified portfolio of fixed-rate nortgage investinents. From the depositor's perspective this is counterproductive to the essential financial service of thrifts, i.e., to issue small denomination shares of diversified portfolios paying market interest rates.

These tax preferences have provided rationales for federal regulation. One tax-policy, the tax preference on owner-occupied housing, results in "excess" mortgage debt issues by middle-income households, justifying protective consumer regulation, and a second tax preference results in this debt being financed by, in part, even lower-income depositors who are less able to diversify and thus are in need of protective deposit regulation. For many years, virtually all consumer protections and safeguards focused on the types of liabilities households were allowed to issue and basically prohibited all but fixed nominal rate instruments. Lenders were subjected to numerous regulations affecting who got credit and at what risk, e.g.,

\section{5/}

For more details on this tax preference and a discussion of its impact on the portfolio behavior of thrifts and the relationship between mortgage and bond rates, see Hendershott and Villani (1980) (1981). 
Truth in Lending, CRA, HMDA and RESPA. Depositors, in contrast, were prohibited from diversifying out of this long-term fixed rate mortgage portfolio by limits imposed on the minimum denornination of alternative investments. Although thrift deposits are essentially equivalent to mutual fund pools in Treasury bills, the yields on Treasury bills were not made generally available to depositors who thus paid the price for the years of protective mortgage regulation. 6

B. Debt Instruments and Returns

In the previous section, we argued that debt instrunents were not essential elenents of finance and that, if issued, would reflect the real value of the underlying collateral. There are thus two issues regarding the use of debt instruments in the current system. The first is why they exist at al 1. The second is why they are denominated in nominal terms. of course, these issues pertain to the entire financial system, not simply housing finance. We have several observations but no definitive answer to the questions.

As al ready explained, households issue mortgage debt because their taxinduced denand for owner-occupied housing generally exceeds net worth. Selling shares in owner-occupied residential capital has not developed as an alternative and would probably result in a loss of the tax preference. This does not explain corporate bonds. Whereas owner-occupied residential capital is tax favored, industrial capital is tax penalized. That is,

6/

See Kane (1970) and Hendershott and Villani (1978, Chapter 6) for discussions of the distributional impacts of ninimum purchase requirements in conjunction with deposit rate ceilings. 
returns to shareholders are taxed twice, at the corporate and individual levels. It is somewhat of an anomaly that double taxation of corporate income leads to the same result with respect to corporate debt as no taxation leads to regarding household debt. Because returns to bondholders are taxed only once, the substitution of bond for equity financing reduces the tax burden on industrial capital generally.

The second reason for the existence of bonds is that it may be more efficient for households to hold bond portfolios than the alternative of fully diversified equity portfolios with options contracts. Diversification is obtained at some costs. Because there are fixed costs of obtaining information, diversification costs are not proportional to portfolio size.

Reasons why debt pays nominal, rather than real, returns are more numerous but less convincing. With respect to owner-occupied residential capital, the most obvious reason is regulatory prohibition. In fact, "equity kickers" have existed in cominercial mortgage contracts for some time. While regulation may have affected the design of mortgage instruments offered by depository internediaries, it does not explain why other firms have failed to originate mortgages paying real returns. A'priori, one would expect mortgage bankers to originate whatever instruments households desire to issue and investors are willing to purchase. There are two constraints on mortgage bankers, however. First, the primary outlets for the loans mortgage bankers originate -- GNMA, FNMA and FHLMC -- are federal or quasi federal. Their regulations in large measure determine the characteristics of mortgage banker-originated loans. If, for example, FNMA follows the recent example of FHLMC in refusing to purchase loans 
with negative amortization, a conventional graduated-payment loan is less likely to develop. Second, there may be economies of scale to mortgage originations that require sufficient volume of issues of any specific type of mortgage to nake the process profitable.

But this does not explain the absence of indexed corporate debt. One reason may be innovation lag. Existing instruments were designed in a noninflationary environment, and tax and accounting procedures developed around these instruments. Dther factors may be the difficulties in choosing the appropriate index and/or appraising the value of residential and industrial capital. Another reason that has been offered (with little enthusiasm) is that lenders as a group are more optimistic about inflation than borrowers (Fischer, 1979).

\section{Underwriting, Brokerage and Exchange}

The preferred tax treatment of mortgages in thrift portfolio's and regulations limiting asset selection also help explain the stricture of the mortgage underwriting industry. Mortgage underwriting conceptually involves the same tasks as bond underwriting. What distinguishes mortgage bajking from investment banking is the greater need for local verification of loans collateralized with residential as opposed to industrial capital. The production function for mortgage loan underwriting is thus quite similar to the production function for denomination intermediation. The thrift industry has, in fact, become increasingly cognizant of the value of the existing plant in producing mortgages as deposit flows have slowed. The development of mortgage "brokerage" services by the FHLMC simply reflects the comparative advantage of thrifts in mortgage banking given their existing physical deposit-taking capacity. 
Much significance has been imputed to the various "secondary" mortgage market institutions: FNMA, GNMA and FHLMC. Actually, these institutions act largely as demanders in the "primary" market for new mortgage securities; they provide little brokerage. In essence, their role is to provide denomination intermediation (to facilitate diversification), as well as to diversify risks of holding mortgages. They also provide ultimate investors an essential element of underwriting, i.e., additional information (Van Order and Villani, 1981). Mortgage bankers provide investors information pertaining to the quality of the collateral. Federal and quasi federal institutions provide information on the quality of the underwriters. There are obvious scale economies to producing and providing this information, which is why, for example, GNMA is actually quite profitable.

Where then, are existing mortgages brokered? The secondary market for these mortgages is made up mostly of private "dealers" who seek out private placements. Trades are relatively infrequent because there is little to be gained. The perceived gains from trade reflect a) the different expectations of the buyer and seller or b) the need for liquidity. Expectations regarding existing mortgages are homogeneous, and few institutions typically need to sell mortgages for liquidity (the 1981 environment is an exception).

The story is somewhat different for owner-occupied residential capital. There are a variety of reasons why people move, some of which are financial. When an owner-occupant moves, ownership must change hands. ${ }^{7}$ This gives

\section{II Simonson and Villani (1981) formally derive the demand for brokerage} services resulting from the homeowner tax preference. 
rise to frequent trades during the life of the house. The real estate brokerage industry is not publicly regulated, but subject only to self-policing of roles of appropriate industry practices established by a representative trade organization.

By definition, the accepted mediums of exchange are currency and demand deposits at conmercial banks. The McCarran-Furguson Act and Douglas Amendinent prevent bank mergers and branching across state lines, resulting in a fragmented industry. Thrift institutions have been prohibited by law from offering demand deposits, resulting in a duplicity of physical capacity to provide a payment mechanism. But the barriers to entry for transactions mechanisins are already crumbling. The implications of this are explained more fully in the next section.

\section{Evolution of the Housing Finance Structure}

In this section first we consider the basic econonic and regulatory forces of change in the existing financial structure and then derive the implications for housing finance. The forces are viewed as driving the system toward the hypothetical unfettered model developed in Section I.8

\section{A. The Forces for Change}

Inflation has been the most powerful economic force behind changes in the financial structure. It has resulted in windfall gains to existing homeowners, increased the demand for owner-occupied housing, and resulted in an explosion in the supply of home mortgage debt (Hendershott and Hsieh, 1980). Simultaneously, it significantly raised nominal interest rates and now

\section{8/}

For an overview of the movement toward financial reform in the United States, see Hendershott and Villani (1978). 
threatens the viability of thrift institutions. These developments have temporarily abated the regulatory and legislative sympathies for borrowers, created empathy for depositors, and heightened concern for the federal insurance funds. The deregulation of deposit rate ceilings, which began in March 1980 with enactment of the Depository Institutions Deregulation and Monetary Control Act ${ }^{9}$, is being accelerated. 10 A decade of debate over the appropriate consumer safeguards in variable-rate mortgage contracts ended with the virtual total deregulation of these contracts. 11 The economic forces in this case simply overwhelmed the existing regulations. Concern with the viability of the federal insurance funds, i.e., the FDIC and more seriously the FSLIC, is providing additional impetus to reform. The first step will be a provision to allow commercial banks to purchase "troubled" thrifts across state lines. This is essentially a device to test the waters for repeal of McCarran-Furguson and the Douglas Amendment. The ultimate step is elimination of prohibitions on branching, mergers and acquisitions.

9/

Deposit rate deregulation provides another example of a belated regulatory response to an innovation, in this case the money narket certificate introduced in June 1978 to circumvent existing regulations.

$10 /$

Thrifts perceived the Depository Institutions Deregulation Committee as proceeding too fast and sued in Federal District Court for slower deregulation in the summer of 1980 . The Congress has criticized the Committee only for moving too slowly, however, and the new Administration has accelerated the pace of deregulation.

$11 /$

In April 1981, several weeks after Richard Pratt became Chairman, the FHLBB issued extremely flexible regulations regarding interest rate adjustability. 
A major distinction between thrifts and commercial banks has been the pronibition of the former from issuing demand deposit liabilities. This law is particularly capricious because the physical capital of the two types of institutions is virtually identical. Higher interest rates on existing deposits and disintermediation enhanced the attractivenes:s of dernand deposits at thrifts. The law was ultinately circumvented first by narketing innovation (e.g., a deposit is not a demand deposit if you do not: call it one) and then by technological innovation (bill-payer accounts by phone, etc.). Thrift institution demand deposits were legitimized in the NOW Account provisions of the Depository Institutions Act.

Further evidence of the belated regulatory response to innovation with the payments mechanisin and the ultinate inability of regulators to prevail is provided by the experience with international banking. Foreign deposits easily evaded American regulations by flowing to other countries. Domestic banks responded by establishing Carribean subsidiaries to handle these funds. In June 1981, the Federal Reserve issued regulations approving the establishment of international banking facilities in the United States, thus ending the prohibition and the flow.

Technological innovation is providing an additional powerful economic force; computer technology will ultinately facilitate a revolution of the transactions mechanism. On May. 29, 1981, the Federal Home Loan Bank Board eliminated existing geographic restrictions on "remote service unit" operations. The rationale for this first step into interstate banking by thrift institutions was parity with commercial banks. 
With this blurring of distinction between thrifts and commercial banks came a similar blurring of distinction between deposit and nondeposit financial intermediaries. Merrill Lynch's cash management account may be the closest substitute to currency as a nationally recognized medium of exchange. As existing financial firms are moving into banking, industrial firms are moving into finance.

Existing tax preferences favoring housing will also be of declining significance. The bad debt allowance will soon be phased out, contributing to the transition of thrifts into banks. The immediate impetus for the removal of the bad debt allowance is provided paradoxically by the current earnings squeeze. This earnings squeeze is attributable to low rates on past inortgage loans, the existence of which is attributable to the bad debt al lowance, limited asset powers and restrictions against variable-rate mortgages. Thrifts have already been granted expanded asset powers; these powers will be enlarged further and the mortgage tax preference will be reduced when thrift earnings make doing so feasible.

\section{B. The Ultimate Financial Structure}

Our point is that economic and technological forces will ultimately -over the next 20 years -- render most existing regulations obsolete. 12 This has three major implications for the financial structure and, in particular, housing finance institutions. First, various types of firms will offer a inedium of exchange. Money transfers will, for the most part, be electronic. Banks and thrifts will still exist (although the two will

\section{1}

For an expanded discussion of regulation-induced innovation in banking, see Kane (1981). 
not be readily distinguishable), but in far fewer numbers and with significantly less physical capital. The prinary purposes of most remaining branches will be to convert small deposits to currency (and vice versa) and to produce mortgages. Federal deposit insurance will contract comensurate with the reduced role of deposit (or denomination) interinediaries, and the two insurers will be merged into one.

Second, mortgage banking subsidiaries will be formed by comnercial bank holding companies, savings and loan service corporations, and investment bankers. For the most part, mortgage origination and mortgage finance will be carried out by separate entities. Mortgages will be financed by various pooling arrangements developed by the above institutions. The federal role in posling mortgages will likely decline in response both to the improved transfer of underwriting information in the private sector and the political backlash to the expanding use of federal guarantees. Private mortgage insurance will play a larger role in the fomation of these pools.

Third, the real estate brokerage industry will be agglomerated. There are currently 600,000 firms, 63 percent of which only have one office (HUD, 1980, pp. II.20 and II.22). The recent entry of Merrill Lynch into the real estate brokerage industry on a national scale will be followed by other firms as the ability to readily transinit information expands. In this regard, one could envisage long-distance sales via tele-communication. In addition, the larger firms with sufficient net worth will become dealers in houses, following the lead of the Merrill Lynch and Sears executive relocation services. Small firms will still dominate in less populated areas where volume is insufficient to achieve the economies of scale necessary for telecommunication and dealer inventory turnover. 
Our previous discussion indicated that the housing finance institutions are unlikely to exist in near their current form by the beginning of the next century. The key issue is what this implies for the financing of owner-occupied housing in the year 2001. The quantity of housing -- as opposed to the quantity of housing credit -- will depend on the real user cost or rental price of housing capital.13 The absolute tax advantage to owner-occupied housing will remain due to politically insurmountable obstacles, but the relative advantage will be reduced by successive reductions in the corporate income tax and increases in accelerated depreciation and investment tax credits. The result will be a general rise in before-tax interest rates and a fall in the demand for housing services. The disappearance of housing finance institutions will have a negligible effect on the quantity of mortgage credit available. In a previous paper (Hendershott and Villani, 1980), we argued that by the end of the past decade housing finance had been substantially integrated with the capital markets, and thus mortgage markets cleared at capital market interest rates. Further, empirical forecasts of housing demand in 1979 and the first half of 1980 suggested that the most recent housing collapse in the United States can be fully explained wi thout appeal to rationing effects (Hendershott, 1980). The expected gradual disappearance of institutions identifiable as "housing finance institutions" is consistent with this integration of markets.

C. The Mortgage Instrument

The most important concern regarding housing finance in the year 2001 is the design of the mortgage instrument. This concern arises from the

$13 /$

See Hendershott (1980) for a recent discussion of the real user cost concept and estimates of its empirical relevance. 
fact that, for many homeowners, mortgage debt will continue to far exceed net worth. The tax advantage will continue to provide incentives to issue mortgage debt, and many households will still not have the flexibility in the remainder of their portfolio to take actions offsetting undesirable mortgage characteristics. To put it another way, sone households may have no alternative to accepting more casin-flow risk in a mortgage contract than their income and balance sheets warrant.

We are not advocating regulation of mortgage contracts. Dur point is that, at least in the short run, thay are designed by existing financial institutions and their regulators and thus reflect existing problems facing the institutions and regulators (insurers). Our concern is that the pendulum nay have swung too far in the direction of depositor and federal insurer interests to redress past grievances. In our view, this appropriately characterizes tine FHLBB regulations issued this spring. Here we assime the pendulun will reach balance within the next several decades (and hopefully much sooner), at which point the mortgage instrument will reflect the needs of the issuer as well as capital narket realities.

The principal change is that mortgage contracts with fixed nominal interest rates will be rare. Most nortgages will contain various provisions for adjustment, as described more fully below. The rate flexibility in the contracts will remove the economic incentive for lenders to require "due on sale" clauses. The application of computer technology will likely result in an adjustable mortgage principal. Thus mortgages will be assumed with greater frequency simply to avoid the transactions costs of repeat underwriting. Similarly, flexible mortgage rates and adjustable loan principal will remove the economic incentive for sorrowers to refinance. 
Finally, the concepts of maturity and amortization will likely lose significance. That is, once the principal balance becomes flexible, a timetable for repaying debt will disappear. The mortgage instrument will resemble a line of credit in this regard, with the maximum balance moving with the current market value of the asset. Lenders and property tax appraisers may combine forces to produce current market appraisals.

The primary concern of borrowers with real rates of interest in mortgage contracts is the cash-flow risks some instruments pose. The traditional problem with the fixed-rate level-payment mortgage is that, with inflation, this mortgage causes too rapid a build-up of real homeowner equity and consumes too large a share of homeowner income. Homeowners unable to issue other forms of debt are constrained to save more income and/or own less housing than they desire. Flexible rate contracts that require full payment of nominal interest when it accrues, in addition to scheduled principal payments (due to amortization), expose the borrower to even greater cash flow risks.

The secondary concern of borrowers regarding real-denominated loans relates to the types of index chosen. There are essentially two ways to index. The first indexes yields to the actual real productivity of the house, in effect converting the mortgage to an equity share. The second way is to index yields to the expost real yield on new capital. An example of the former is the shared-appreciation mortgage (SAM). Technically, the lender receives a share of the appreciation -- either when the house is sold or at some prespecified date -- as an interest payment. But the amount of this payment will reflect the real expost productivity of the 
specific housing capital and is thus in essence an equity interest. An example of the latter is the variable-rate mortgage, e.g., the Wachovian Plan. 14 The yield under this plan is indexed to the new-issue six-inonth Treasury bill rate.

The first type of index provides a complete hedge to the homebuyer. Lenders can diversify their implicit residential equity shares to earn the average expost real rate on housing equity by diversifying the SAM portfolio. With the Wachovian plan, the lender earns the actual real return on new capital in each future period; households thus bear both the risk of the return on an individual house being below average and the risk that future real returns will rise above returns on existing residential housing. The SAil is thus the preferred real-denominated mortgage contract from the borrower's perspective. Moreover, it may be preferred from society's viewpoint in that lenders are far better able to diversify away the risk of returns on individual houses.

\section{Summary}

There are four essential services provided by a financial system: a medium of exchange, security underwriting, security brokerage, and denomination intermediation. These avoid the costs of barter, increase the productivity of investinent by separating the investinent and saving decisions, reduce

\section{$14 /$}

This plan was first introduced by the Wachovian National Bank in North Carolina. Variants have sprung up around the country. Presently (June 1981) Wachovian mortgages al so reduce the cash-flow problems of borrowers because mortgage payments are based on a $133 / 4$ percent interest rate, far below the 16-17 percent rate available on fixed-rate mortgages. 
transactions costs by providing marketability or liquidity, and lower risk by permitting asset diversification. In a housing finance system unfettered by nonneutral taxes and regulations, residential capital would be financed by equity shares and (mortgage) debt; nortgage underwriters would originate real-denominated housing finance instruments (paying real returns and indexed, at least roughly, to the nominal value of the underlying house asset); and financial institutions would facilitate portfolio diversification by holding a wide variety of assets, including mortgages, and offering small denomination liabilities.

The current housing finance system in the United States differs widely (at least until very recently) in all respects from this hypothetical model. That large part of residential capital which is owner-occupied is financed by a single equity share (100 percent ownership); mortgages have carried fixed nominal rates and negative amortization has been precluded; and housing finance institutions exist with undiversified portfolios. These differences can be attributed virtually entirely to the existence of nonneutral taxes and a myriad of government regulations. Because the tax subsidy to homeownership is available only to owner-occupiers, there are strong incentives against issuing multiple equity shares. Because tax preferences for thrifts are contingent upon large percentage investment in mortgages, thrifts hold undiversified portfolios. Finally, regulations, or the threat of them, have prevented thrifts from originating variable-rate mortgages and investing in certain classes of assets.

The driving force for change of the housing finance system has been the acceleration of inflation. Increased nominal interest rates have 
threatened the viability of thrift institutions and created enorinous cashflow problems for homebuyers. As a result, regulators now favor variablerate mortgages, and mortgages with negative amortization -- graduated payment, shared-appreciation, and Wachtovian -- are being utilized. Moreover, because returns on shared-appreciation mortgages are tied to the movement in the price of the underlying house, this instrument is equivalent to an equity and allows diversification of part of the risk of investment in individual houses. We expect such instruments to become widespread in the future. The early disappearance of fixed-rate mortgages is obvious. Other likely changes affecting housing finance include the following. The tax preferences of thrifts and relative tax advantage of owner-occupied housing will be reduced, the latter by cutting effective tax rates on other assets (reductions in the corporate and capital gains tax rates and increases in tax depreciation and investment tax credit). There will be fewer brokerage firms and financial institutions, and there will be few, if any, undiversified "housing finance" institutions. Mortgage origination and finance will be carried out almost entirely by different institutions. Finally, the federal role in housing finance and insurance will be contracted. The reduction in the relative tax advantage for owner-occupied housing will obviously tilt households away from ownership and tend to reduce the quantity of housing desired, but the developinent of mortgages with negative amortization will act to raise housing demand. The projected demise of traditional housing finance institutions will have little impact on housing deinand because the mortgage market is al ready integrated with capital markets generally. 


\section{References}

Arrow, Kenneth J., "The Role of Securities in the Optimal Allocation of Risk Bearing," Review of Economic Studies, Vol. XXXI (2), 1964.

Brunner, Karl and Allan H. Meltzer, "The Uses of Money: Money in a Theory of an Exchange Economy," American Economic Review, December 1971.

Fischer, Stanley, "Corporate Supply of Index Bonds," NBER Working Paper 331, March 1979.

Gurley, John G. and Edward Shaw, "Financial Intermediaries and the SavingInvestment Process," Journal of Finance, May 1956.

Hendershott, Patric H., "Real User Costs and the Demand for Single-Family Housing," Brookings Papers on Economic Activity, 2: 1980.

Hendershott, Patric H. and Chang-Tseh Hsieh, "Inflation and the Growth in Home Mortgage Debt, 1964-78," Journal of Financial Research, Fall 1980.

Hendershott, Patric H. and James D. Shilling, in Sirmans (ed.), Research in Real Estate, Vol. I, JAI Press, Inc., 1981.

Hendershott, Patric H. and Kevin E. Villani, Regulation and Reform of the Housing Finance System, American Enterprise Institute for Public Policy Research, Washington, D.C., 1978.

Hendershott, Patric H. and Kevin E. Villani, "Savings and Loan Usage of the Authority to Invest in Corporate Bonds," Savings and Loan Asset Management Under Deregulation, Proceedings of the $6 \mathrm{th}$ Annual Conference of the Federal Home Loan Bank of San Francisco, 1981.

Hendershott, Patric H. and Kevin E. Villani, "Secondary Residential Mortgage Markets and the Relative Cost of Mortgage Funds," American Real Estate and Urban Economics Association Journal, Spring 1980.

HUD's DRAFT RESPA - Section 142: The Real Estate Settlement Procedures Act, Volume II: Settlement Performance Evaluation, (Washington, D.C.: U.S. Department of Housing and Urban Development, Office of PD\&R, October 1980).

Kane, Edward J., "Accelerating Inflation, Technological Innovation, and the Decreasing Effectiveness of Banking Regulation, Journal of Finance, May 1981.

Kane, Edward J., "Shortchanging the Small Saver: Federal Government Discrimination Against Small Savers During the Vietnam War," Journal of Money Credit and Banking, November 1970.

Rosen, Harvey S. and Kenneth T. Rosen, "Federal Taxes and Homeownership: Evidence From Time Series," Journal of Political Economy, February 1980. 
Silber, William B., "Towards a Theory of Financial Innovation," in Silber (ed.) Financial Innovation, Lexington Books, D.C. Heath and Company, 1975.

Simonson, John C. and Kevin E. Villani, "Real Estate Settlement Pricing: A Theoretical Framework, presented at the 9th Annual Mid-year Meetings of AREUEA, May 1981.

Van Order, Robert and Kevin E. Villani, "A Study of the Conventional GNMA Pass-Through Security," HUD Occasional Paper Series, June 1981. 